\title{
The ecology of mining. Human-environmental relations in the Medieval and Early Modern mining in Central Europe
}

\author{
Key words: mining archaeology, settlement, man-environment, Middle Ages, Early \\ Modern Period \\ Słowa kluczowe: archeologia górnictwa, osadnictwo, człowiek-środowisko, średniowiecze, \\ wczesna nowożytność \\ I. Introduction. II. Wood demand and deforestation. III. Soil deterioration. IV. Water. \\ V. Air. VI. Impact of toxic substances on the local population. VII. Living conditions \\ in mining regions. VIII. "Ecological awareness" in mining regions and attempts \\ for natural resource protection. IX. Conclusion
}

\section{Introduction}

Medieval mining in Western and Central Europe started in the $10^{\text {th }}$ century and experienced a period of significant rise in the $13^{\text {th }}$ century as a result of developments in agriculture, population increase, the rebirth of towns, and expanding markets ${ }^{1}$. The constant demand for silver and other metals forced people to look for and exploit new deposits. This phenomenon was especially prevalent in the Central European region, including Upper Saxony, Silesia, Bohemia, Moravia, and present-day Slovakia ${ }^{2}$. After the technical and financial crisis during the $14^{\text {th }}$ and the first half of the $15^{\text {th }}$ century ${ }^{3}$, mining flourished in the $16^{\text {th }}$ century on a much bigger scale than before ${ }^{4}$. Mining brought an enormous interference in the natural environment. Miners and smelters cut the wood, destroyed the landscape, contaminated soils, water, and air. This influence can be traced in historical, archaeological, and environmental sources (such as geochemical and paleobotanical records). Despite the dynamism of the changes that took place in many medieval mining regions, it is possible to trace the relations between the natural and built environment and the local population. Thanks to the advances in environmental analysis triggered by the issues related to the modern industry, we can estimate the impact of past mining and metalworking practices on the environment and human health. This process can be seen in a longue durée perspective, from the earliest phases of the industrial era until present times. Mining centres established during the two aforementioned phases of mining development functioned for a long time. In some cases, the lasting effects of medieval and early modern mining works are still visible, showing the far-reaching roots of some of the modern landscapes.

This paper addresses the question of how mining and smelting operations changed the natural environment and how society reacted to these changes. The key issues that I will focus

\footnotetext{
${ }^{1}$ Le Goff J. 2002; Gawlas S. 1996; idem 2006.

${ }^{2}$ Molenda D. 1963, chapter I.

${ }^{3}$ Nef J.U. 1978, pp. 721-723.
} 
on are deforestation, waste management, soil deterioration, and pollution. Next I will examine how those factors influenced living conditions of the local population. The study is based on archaeological, historical, and environmental sources from the Black Forest (Schwarzwald), the Harz Mountains, the Ore Mountains (Erzgebirge), Silesia, Lesser Poland, Bohemia, Moravia, and modern-day Slovakia. The mining districts in all these regions during the late Middle Ages and Early Modern Period were strongly interconnected. That is why the mining technology and the way of life were similar in all of them and, therefore, they can be studied as a homogeneous phenomenon.

The topic of the human-environment relation in mining districts has not been comprehensively analysed so far. A number of studies tackled such issues as wood management ${ }^{5}$ or mining impact on the natural environment in Germany ${ }^{6}$. However, mining regions in the Czech Republic, Poland, and Slovakia are less researched. Earlier studies were often based on ethnographical and experimental or historical sources, while more recent approaches, based on scientific methods ${ }^{7}$, opened a range of new possibilities ${ }^{8}$ making it is possible to summarise key issues.

Mining strongly interferes with the natural environment as it leads to deforestation and landscape degradation. In terms of human impact, the biggest threat is pollution caused by ore processing. These processes intensified with the development of mining on a larger scale. People living in mining regions were therefore exposed to many health risk factors related to contamination, but their quality of life and incomes resulting from mining work could have counterbalanced some of these effects.

I will analyse the problem of mining ecology starting with the human influence on woodlands, then I will show how mining and smelting affect landscape, soils, water, and air. After that, I will examine the influence of the changes in the environment on human health. The next step is to investigate the living conditions in mining regions, especially the relation of settlements to the production areas. Finally, I will try to answer the question concerning the opinions and level of awareness of people about environmental degradation, as well as their efforts to address the problem.

\section{Wood demand and deforestation}

Playing an indispensable role in the ancient economy, forested areas were teeming with human activity in the Middle Ages and Early Modern Period. They provided food for people and animals, building materials, raw materials for craftsmen and, most importantly, fuel for metal smelting, glassworks, pottery furnaces, breweries, and households 9 .

The mining and smelting industry was one of the largest wood consumers. In the mines, wood was used first and foremost to construct timbering in mines and other infrastructure. If the bedrock was strong enough, extensive protections were unnecessary, but a lot of complicated constructions were needed. Timber was also used to build water conduits, ore washers, warehouses, residential buildings, and transport infrastructure, as well as to manufacture tools. It is difficult to establish the total demand as it depended on the geological structure of the mined deposits and their type, as well as extraction methods. Another activity related to mining that exploited forests was charcoal production. Charcoal was the main fuel used for smelting operations up to the $18^{\text {th }}$ century and was consumed in great quantity.

\footnotetext{
${ }^{4}$ Delumeau J. 2006, pp. 63-65.

5 Hillebrecht M.-L. 1982; eadem 1985; eadem 1989.

${ }^{6}$ Goldenberg G. 1993; idem 1996.

${ }^{7}$ Ludemann T. 2010; Breitenlechner E. et al. 2010.

8 Iles L.E. 2016.

9 Schubert E. 1985, pp. 253-257.
} 
It is difficult to say how much wood was used during smelting. This amount was probably larger than during the extraction process. The quantity of fuel was dependent on the number of smelting process stages, used technology, the composition of ore, and wood species used in charcoal production. In every mining region, the quantity of fuel could be different. Some information about the level of wood used during the mining process came from Horní Slavkov. It is not very accurate but shows the scale of the wood use. Tin ore was first roasted to clean it from impurities and then smelted. Roasting of one Rost of ore (36,5 t) took 10-12 hours and demanded 19 cubic meters of firewood, an equivalent of 38 average sized trees. This means that 24.000 trees were consumed in Horní Slavkov each year for roasting ore alone. In the next step - smelting to prepare one Zentner of tin (about $50 \mathrm{~kg}$ ) — it was necessary to burn charcoal obtained from 2.3-5 cubic meters of wood (i.e., 5-10 trees) ${ }^{10}$.

The exact consumption patterns and quantities depended on the wood quality. The most desirable species for charcoal production were beech (Fagus sp.), oak (Quercus $s p$.), and birch (Betula sp. $)^{11}$. Construction timber also has different properties depending on the species and can be used for different purposes. Timber for mining structures was selected according to its strength, hardness, flexibility, cleavage, and durability. Research undertaken in mines in the Black Forest region demonstrated that miners preferred fir (Abies sp.), spruce (Picea sp.), oak, and beech. Pine (Pinus sp.) was used rather rarely because it breaks easily and rots rapidly. Fir was used mainly for temporary applications, whereas spruce — a moisture resistant tree with a straight trunk — was used to make posts. The wood of deciduous trees was also commonly utilized in construction and for other uses ${ }^{12}$. Although lumbering was undertaken depending on the tree species composition of the forest and local needs, even selective tree cutting could have decimated a forest and upset its ecosystem. Weaker forests were more susceptible to strong winds and heavy snowfall. In a short time, the land around a mining centre could become totally deforested ${ }^{13}$ or dominated by forest monocultures, characterised by decreased biodiversity and productivity.

The level of deforestation was directly proportional to the scale of the mining operations, and therefore most pronounced in larger mining centres. The traces of medieval deforestation were studied during an examination of charcoal samples found at several archaeological sites in the Harz Mountains (Germany). The primary forest in the region was deciduous, mostly consisting of beech and maple (Acer sp.), as well as some spruce. Before the turn of the second millennium $\mathrm{AD}$, the anthropogenic impact was so small that the forest could naturally regenerate itself. However, after that date, it began to be exploited for mining purposes. In the first phase, only trees that were the most useful for the charcoal production (especially beech) were cut down. That probably was the cause of the spruce expansion. Pollen analyses revealed a change in the species composition in layers dated to the period after the year 1200, which correlates with the intensive growth of the mining industry in the region. Samples taken from charcoal piles have shown that during that period "soft" tree species, less suitable for charcoal production, e.g. birch, hazel (Corylus sp.), poplar (Populus sp.), sorb (Sorbus sp.), and willow (Salix sp.) were used alongside the traditional "hard" ones, such as beech and oak. Research conducted on a site Johannes Kurhaus near Clausthal-Zellerfeld, where relics of charcoal piles and smelters were found, indicates that in the oldest contexts wood from natural forests (beech, oak) was the most common, but its amount decreased with time. The fact that small-diameter trees were cut down every 10-20 years provides evidence of forest overexploitation. The percentage of pioneering species, e.g. birch, hazel, sorb, and willow substantially increased

\footnotetext{
${ }_{10}$ Majer J. 1997, pp. 234-237.

${ }^{11}$ Frenzel B., Kempter H. 2011, p. 108.

12 Straßburger M., Tegel W. 2009, p. 183.

13 Majer J. 1997, p. 224.
} 
(more than 45\%) in a process of ecological succession ${ }^{14}$. Deforestation was probably provoked by a high rate of metal production as more sustainable exploitation would not lead to deforestation. Recent research on charcoal production in the Black Forest and the Vosges suggested that there is evidence of massive deforestation and change of species in the primeval forest during the Medieval Period ${ }^{15}$. However, proper wood management could prevent forests from being overexploited (see below).

The Harz example also reveals another problem of medieval and early modern forestry: the transportation of timber. Until the $19^{\text {th }}$ century, land transport was unprofitable ${ }^{16}$. Forests that were remote from main communication routes, especially rivers, were underexploited as timber transported by land for more than 7-8 hours became too expensive ${ }^{17}$. In Kutná Hora during the $16^{\text {th }}$ century, wood was transported by horse from distances of about $40 \mathrm{~km}^{18}$, but although it is hard to say exactly how much time it took it was probably still profitable. Wood for Kutná Hora's mines and smelters was also floated in the Elbe River from the Trutnov forests (about $80 \mathrm{~km}$ in a straight line). In the last $3 \mathrm{~km}$, logs were drifted in an artificial canal ${ }^{19}$. In areas with no natural rivers, longer canals were built, such as a canal built in 1525 in the Slavkov Forest region (West Bohemia), which was $30 \mathrm{~km} \mathrm{long}^{20}$.

Until canals were built, the forests around the mining area were used first. Although it is difficult to establish how quickly available forest was cut down, there are some estimates available for Bohemia. Based on data concerning production levels in Jáchymov, Majer (1997) estimated that from 1516 to $160065,000-90,000$ ha of forest was cut down, that is $750-950$ ha per year. As trees were cut down around the town in the mid- $16^{\text {th }}$ century, forests within a 10 $\mathrm{km}$ radius of Jáchymov (about $2930 \mathrm{ha}$ ) were reserved for mining purposes. Another 1000 ha were added in the 1660s and 1670s. A similar situation occurred in Horní Slavkov during the 1540 s, when timber was imported from 20-25 km away. By the middle of the century, timber supply plunged to such a critical level that it threatened the mining production ${ }^{21}$.

One of the biggest challenges in the study of forest exploitation and wood demand is estimating forest production capabilities. Data concerning wood consumption relies mostly on estimates based on historical sources rather than on experiments, which may introduce some inaccuracy. Furthermore, obtaining unequivocal data is difficult because of many variables such as the type of ore and the processing method. The scale of mining production is also difficult to establish, especially for the Middle Ages. The most efficient method in determining the rate of deforestation is most likely pollen and charcoal analysis, but it can only be conducted in locations where environmental samples are available.

\section{Soil deterioration}

Another aspect of the environment that was strongly affected by mining operations was the soils and the landscape. Deforestation and mining work often led to increased rates of erosion and, in some cases, even to desertification.

The first cause of erosion was deforestation carried out to find the ore deposits, obtain wood or clear space for fields and pastures. Mining works intensified that process ${ }^{22}$. Especially in hilly

${ }_{14}$ Hillebrecht M.-L. 1982, pp. 89, 114, 126-29; eadem 1985, pp. 274-275; eadem 1989, pp. 82-84.

15 Ludemann T. 2010.

16 Gleitsmann R.-J. 1984, p. 28.

17 Wilsdorf H. 1960, p. 36.

18 Kořan J. 1950, p. 94.

19 Bartoš M. 2004, pp. 18-24.

${ }_{20}$ Majer J. 1997, p. 236.

21 Ibidem, pp. 222-226.

22 Goldenberg G. 1993, p. 108. 


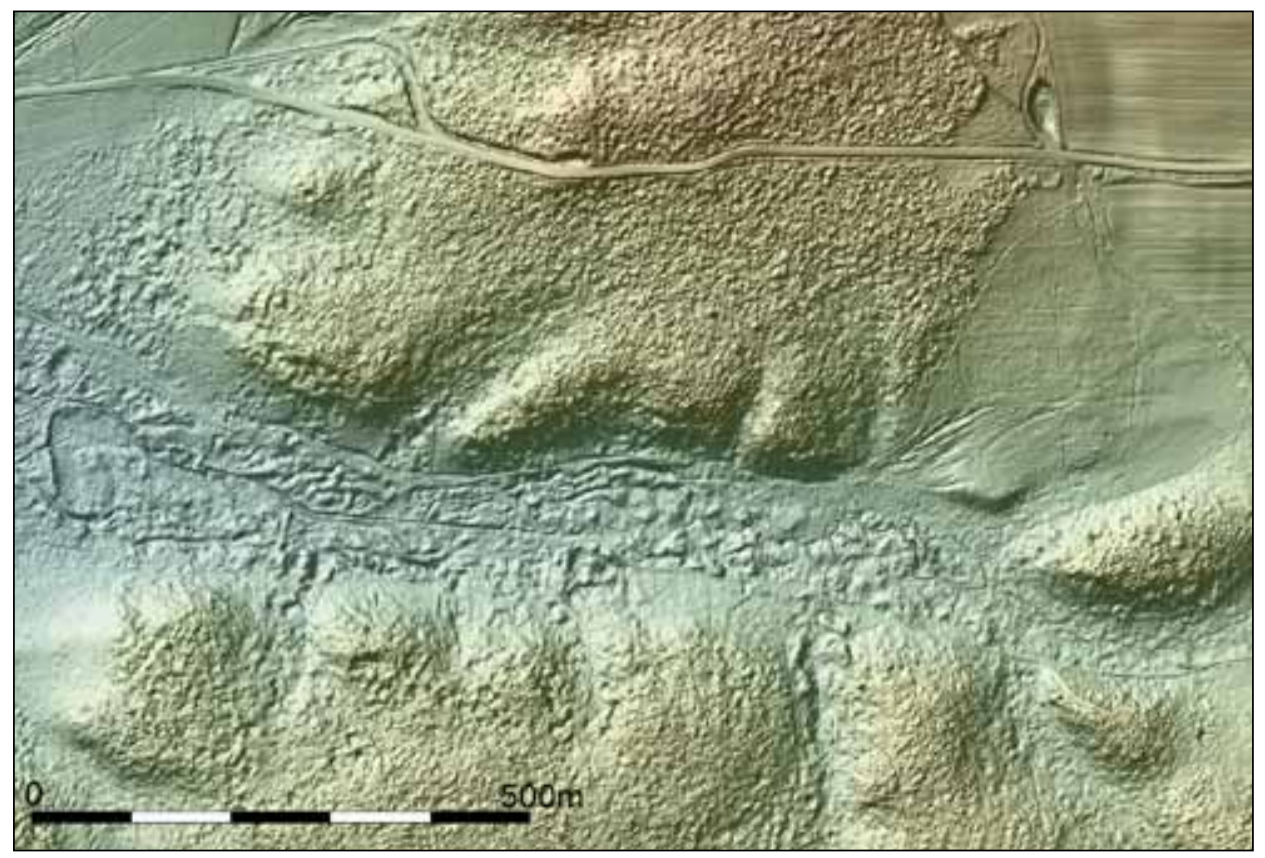

Fig. 1. Digital Terrain Model of a mining field on a secondary gold deposit in Lwówek Śląski (prepared by M. Legut-Pintal)

Ryc. 1. Cyfrowy Model Terenu pól górniczych na wtórnych złożach złota w rejonie Lwówka Śląskiego (oprac. M. Legut-Pintal)

and mountainous regions, slopes became susceptible to precipitation, which in turn accelerated sedimentation in the valleys. During research in the Sulzbach Valley (the Southern Black Forest), two phases of the formation of the valley bottom were observed. The first took place during the Roman period and the second during the High Middle Ages. Those processes were connected with mining operations as is confirmed by medieval and late medieval slag heaps covered by a $10-100 \mathrm{~cm}$ thick layer of sediment ${ }^{23}$.

The scale of deterioration connected with the mines depended on methods used to extract ores, which, in turn, were adjusted to the types of the mined deposits. The most common were vein deposits. After the discovery of the ore, extraction was carried out along the vein and, for as long as it was possible, in an open pit. At a later stage or if the vein ran deeper, miners would start digging vertical shafts and horizontal galleries. If ore was concentrated in nests, it was necessary to dig many exploratory shafts. The extraction of nests created many underground chambers. After some time, separate mines were connected by tunnels to facilitate transport and ventilation. In the early phase of industrial mining, ore was extracted above the water table to prevent mines from being flooded. When gravity or mechanical drainage was introduced, it was possible to also start extracting ore under the water table. In the Middle Ages, while exploring, miners tried to draw out as little gangue, that is worthless material surrounding the ore, as possible ${ }^{24}$. In case of secondary deposits, like gold sand, huge mining fields were created filled with open pits and shafts dug next to each another. For example, the digital terrain model (based on LIDAR scan)

${ }^{23}$ Ibidem, pp. 233-234.

${ }^{24}$ Molenda D. 1963, pp. 98-108; Dziekoński T. 1972, pp. 68-69. 
of the area around Lwówek Śląski (Lower Silesia, Poland) uncovered 600 ha of land known to have been taken up by medieval gold mining (Fig. 1$)^{25}$.

Another factor contributing to erosion was the drainage. Soils stripped of plants were more vulnerable to erosion. The scale of this process depended on drainage methods used in mines: mechanical or gravitational. The first one consists of drawing water with a bucket attached to a rope or with a more complicated system of pumps powered by water or a horse. The resulting cone of depression was limited to the vicinity of the drainage shaft. In contrast, gravitational drainage consisted in constructing a gently sloping underground gallery that naturally led water to the nearest stream. The resulting cone of depression could go as far as a hundred meters away from the gallery and was permanent ${ }^{26}$.

Deforestation additionally led to the impoverishment of soil and to the desertification of the landscape, which is well illustrated by the relics of a medieval and early modern production site in Hutki (Poland). Remains of ore washers and a smelting furnace dated to the $15^{\text {th }}$ and the first half of the $16^{\text {th }}$ century were discovered there under a layer of sand $3 \mathrm{~m}$ thick (Fig. 2). This deposit was probably formed after the surrounding forest was cut down to build a drainage gallery $^{27}$. The Błędowska Desert, a ca. $40 \mathrm{~km}^{2}$ sandy area located $10 \mathrm{~km}$ north of Olkusz (Poland), was probably formed because of the same deforestation process that took place in the $16^{\text {th }}$ century. The desert was originally much larger and included an area west of Olkusz. Mining operations ceased there in the late $20^{\text {th }}$ century.

So far there has been no attempt to describe the scale of landscape change in any of the main mining centres or its relation to the settlement network. Mining must have affected fields and pastures, rendering them unusable for prolonged periods of time. Soil degradation leads to the lowering of agricultural production capacity. As a result, it would have been necessary to transport food from more distant locations and thus purchase it at a higher price. Such conditions would have worsened the quality of life of the local population.

Mining and smelting activities introduced a higher concentration of heavy metals in the soils. The main source of such pollution were residues from primary and secondary ore processing, but toxic substances were present at every stage of the metal production.

After being extracted, ore was crumbled and sorted near the mine. Any worthless chunks were dumped with the extracted gangue onto a mound close to the shaft. After years of mining operations, such dumping fields changed the surrounding landscape, a phenomenon well documented in Kutná Hora (Czech Republic). The town developed directly on mining fields and in many areas in its centre the layer of gangue is $2-5 \mathrm{~m}$ thick. Most buildings sit on mining dump residues ${ }^{28}$. This dump mounds contained toxic residues that were moved around by rainwater, thus contaminating the soil.

The most contaminated areas were in places were pure ore was processed (crumbled, washed, ground, roasted, and smelted). This can be seen at the $13^{\text {th }}$-century mining site of Cvilínek u Černova near Pelhřimov (Czech Republic). Measurements taken on the site have shown that the concentration of lead is close to $3000 \mathrm{mg} / \mathrm{kg}$, of arsenic to $3700 \mathrm{mg} / \mathrm{kg}$, of zinc to $3000 \mathrm{mg} / \mathrm{kg}$, and of copper to $270 \mathrm{mg} / \mathrm{kg}^{29}$. For comparison, the present-day Polish soil pollution scale recommends that cereals or vegetables should not be produced when the levels of toxic elements in the soil exceed the following limits (depending on the soil type): 500-2000 $\mathrm{mg} / \mathrm{kg}$ for lead, $700-3000 \mathrm{mg} / \mathrm{kg}$ for zinc, $100-150 \mathrm{mg} / \mathrm{kg}$ for copper, $100-300 \mathrm{mg} / \mathrm{kg}$ for

${ }^{25}$ Cembrzyński P., Legut-Pintal M. 2014, p. 191.

${ }^{26}$ Czaja S. 1996, pp. 18-24.

${ }^{27}$ Pierzak J., Rozmus D. 1997, pp. 188-193; Pierzak J. et al. 2004, pp. 81-92.

${ }^{28}$ Frolík J., Tomášek M. 2002, pp. 99-100.

${ }^{29}$ Hrubý P. et al. 2012, p. 359. 


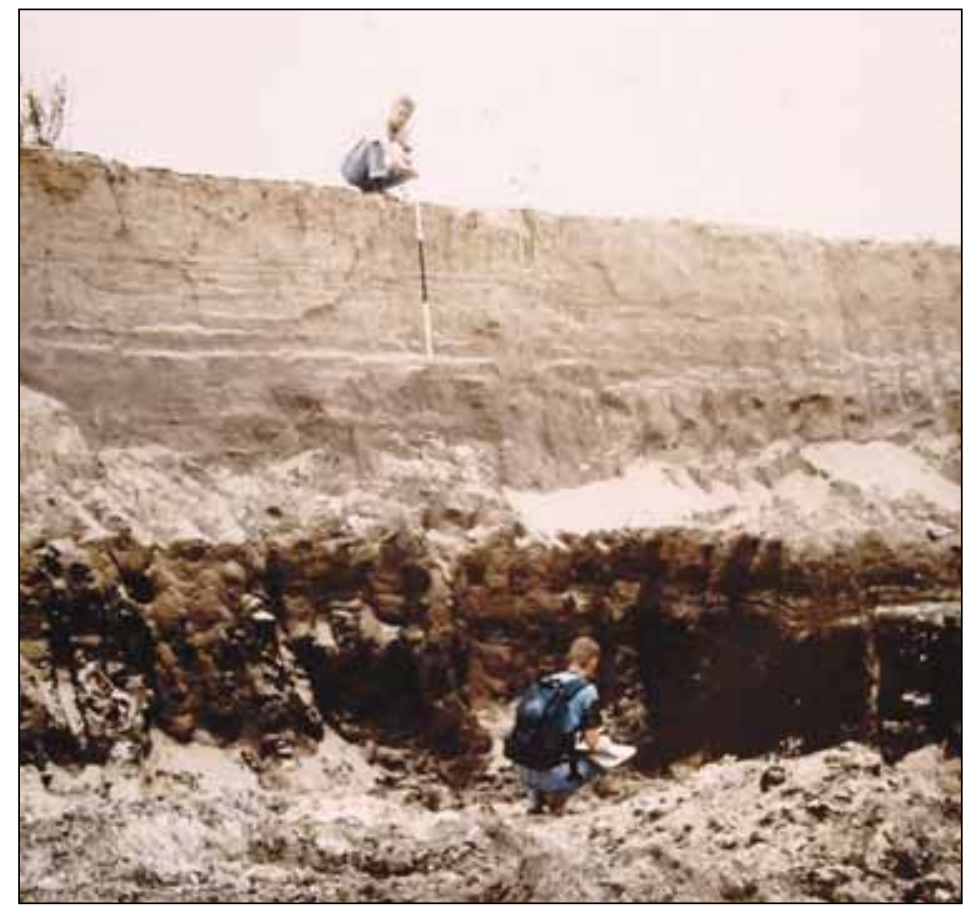

Fig. 2. Sand sediments over the $15^{\text {th }}-16^{\text {th }}$ century smelting site in Hutki near Olkusz (by D. Rozmus)

Ryc. 2. Warstwy piasku przykrywające osadę hutniczą z XV-XVI w. w Hutkach koło Olkusza (fot. D. Rozmus)

nickel, $3-10 \mathrm{mg} / \mathrm{kg}$ for cadmium ${ }^{30}$. All the levels of toxic elements at Cvilínek were on the high end of the scale or exceeded the norms by a factor of up to two. It is obvious that this site was not an appropriate place for food production. An even worst situation could be found at the smelting sites. Samples taken at the site of Schnapsweg (ca. 1000 AD) in the Harz Mountains, showed that the level of lead contamination was 28 times higher than the mentioned present-day norms. It was 140 times higher for copper and 180 times higher for zinc. Even today the concentration of heavy metals in medieval smelting sites of the region is very high, and its primarily toxic-resistant plants that are able to grow there ${ }^{31}$.

\section{Water}

Water played an important role in spreading the contamination since it transported toxic substances over long distances. The dump mounds increased the levels of pollution only locally, but streams and rivers played the main role in the medium and long-range pollution. One of the ore processing stages was washing. Crumbled ore was washed in a system of canals and broken into smaller pieces. Water resulting from this process containing small particles of dump and minerals was then released into the nearest stream. In the $16^{\text {th }}$ century in the Harz Mountain stamp, mills were improved by adding washers to them. This increased the amount of ore that

${ }^{30}$ Kabata-Pendias A., Piotrowska M. 1995, pp. 18-19.

${ }^{31}$ Deicke M. 2000, pp. 71-73. 


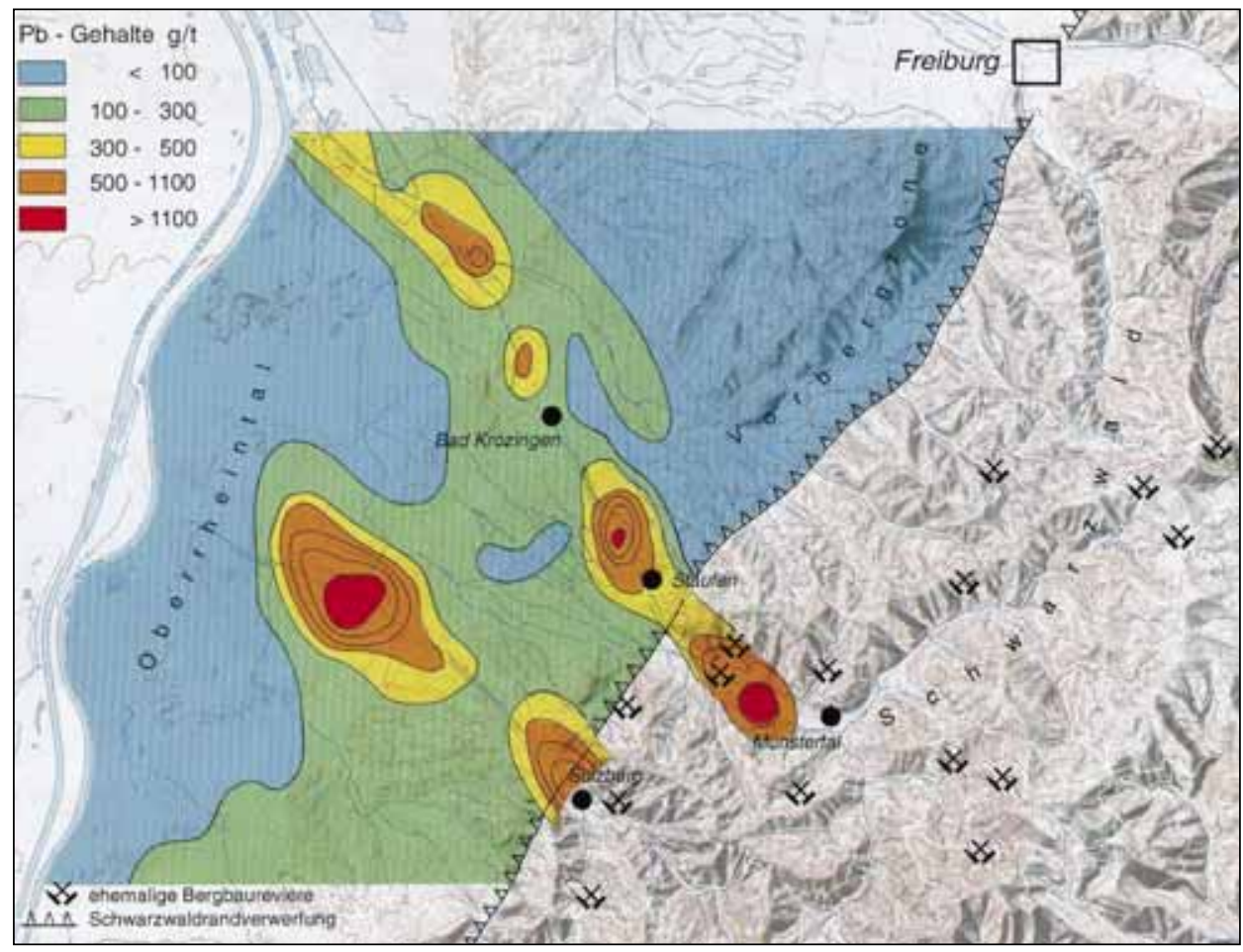

Fig. 3. Mining-related contamination with $\mathrm{Pb}(\mathrm{g} / \mathrm{t})$ in South Schwarzwald (after Goldenberg G. 1993, p. 113)

Ryc. 3. Zanieczyszczenie ołowiem (g/t) związane z górnictwem w rejonie południowego Schwarzwaldu (Niemcy) (za: Goldenberg G. 1993, s. 113)

was getting into the water. It is estimated that in some cases up to $75 \%$ of the ore was wasted during the crumbling and washing process ${ }^{32}$.

Small particles of ore were transported by water to distant places. Research showed that in streams close to the mining area the content of heavy metals in bottom sediment was very high ${ }^{33}$. Smaller and bigger streams transported toxic substances down towards the major rivers. Increased levels of lead, copper, zinc, and cadmium in soils were observed in the southern Black Forest, in the tectonic foreland connected with the mining water disposal network (Fig. 3) 34 $^{34}$ However, the nearest surroundings of the mines were not the only areas affected by contamination. For example, in 1982, a flood uncovered clay strata from around 1350 AD near Bremen (Germany). The sediments were part of a watercourse network that had its sources in the mining regions of Harz, Hessen, and Sauerland (200-250 km away). In those strata, the concentration of zinc, lead, copper, arsenic, cadmium, chrome, and nickel was 250 times higher than the average for the Bremen region. According to scientists, all those elements were washed out from mining regions, where deforestation had caused erosion exposing contaminated soils $\mathrm{s}^{35}$. Even though in

32 Bartels C. 1996, p. 484.

33 Bühler H.-E., Wild H.W. 1991, pp. 155-156.

${ }^{34}$ Goldenberg G., 1993, pp. 112-113; idem 1996, pp. 236-237.

35 Bartels C. 1996, pp. 483-484. 
the more distant areas the concentrations of heavy metals in soils were usually not very high and soil was still arable, the contamination was permanent or lasted a long time.

\section{Air}

Another element of the biosphere that suffered from the ore processing industry was the air quality. Dust and smoke coming from roasting piles and furnaces were full of toxic substances. Most of them fell on the ground with rain and snow, while about $1 \%$ stayed in the atmosphere and was transported over longer distances ${ }^{36}$. The evidence of that process can be found in the traces of heavy metals in peat bogs, lake sediments, and ice, which can be viewed as "geochemical archives" providing us with information about changes in pollution intensity at the time of their formation ${ }^{37}$. They can also be helpful in measuring the spatial extent of pollution.

Dust and smoke spread depended mostly on the localization of furnaces. Simple furnaces with natural ventilation blow were enough for smelting rich ores. Until the end of the $12^{\text {th }}$ century, many smelting sites in the Harz Mountains were located on hilltops, where strong winds guaranteed a good supply of oxygen. However, such a location meant that toxic fumes were expanding over a wider area ${ }^{38}$. When mining developed and rich ores were exhausted, it was necessary to smelt poorer ore in larger amounts. New smelters were built in valleys close to the streams. There it was possible to install water wheels to propel bellows. Furnaces probably did not have high chimneys so most of the toxic fumes stayed close by, leading to concentrations especially dangerous in case of ores that contained sulphur. Sulphur dioxide forms during roasting and can harm plants around the furnace ${ }^{39}$.

All these examples indicate that toxic substances were a by-product at every stage of metal production, making a harmful impact on the natural environment and, in particular, on human health.

\section{Impact of toxic substances on the local population}

It is difficult to study the health condition of past population mostly because of the lack of direct evidence. Nevertheless, one can imagine that a devastated environment, hard labour, and the presence of toxic substances had some effect on the health of the local population. Present day knowledge about heavy metals and their influence on living organisms can provide an insight into how miners and their families suffered.

Humans absorb heavy metals, like other trace elements, through ingestion (foodstuff, water, soil, aerosols), inhalation (aerosols, gases) or through skin contact (soil, water, aerosols, gases). Most trace elements accumulate in soft tissues, especially in the liver and kidneys. The food chain is considered the main tract for the transfer of trace elements into humans ${ }^{40}$.

The most common heavy metals occurring in mining regions are zinc, cadmium, lead, and arsenic. Large doses of zinc can damage the alimentary tract and cause diarrhoea and fever. Workers who inhale high levels of zinc dust or fumes can suffer from a short-term illness called the metal fume fever. It causes chills, fever, excessive sweating, and weakness of the body ${ }^{41}$. One of the most toxic substances, a by-product of the medieval and early modern mining industry, was cadmium. Its excess may cause renal damage, hypertension, emphysema, carcino-

36 Patterson C.C. et al. 1970, p. 339.

37 Bohdálková L., Erbanová L. 2013, p. 83.

38 Ruppert H., Deicke M. 2006, p. A545.

39 Deicke M. 2006, p. 73.

${ }^{40}$ Kabata-Pendias A., Mukherjee A.B. 2007, p. 73.

${ }^{41}$ Ibidem, p. 293. 
genic changes (especially in the kidneys and the prostate), skeletal deformation, and the impairment of reproductive functions. Cadmium intake occurs mainly through the inhalation and ingestion of food and drink. The atmospheric concentration of cadmium is especially high close to zinc-lead ore smelters ${ }^{42}$.

Another highly toxic metal is lead. Workers of lead-zinc ore mines and smelters were especially at risk of inhaling it. It accumulates mostly in soft tissues and bones and its excess may inhibit heme formation, damage the nervous system and kidneys, cause anaemia and the impairment of mental development in children, as well as lead to carcinogenicity, genotoxicity, and an impairment of reproductive functions ${ }^{43}$. The intake of large quantities of lead may cause death $^{44}$. Lead was also used in large quantity in copper production to separate silver from copper in the Seiger process ${ }^{45}$. Another very hazardous element present in some types of ores is arsenic. When inhaled, it can cause neurological symptoms, cardiovascular disease, respiratory disorders, hypertension, diabetes mellitus, keratosis, and even cancer ${ }^{46}$.

One of the methods available for investigating how hazardous the environment and work conditions were in the past and their impact on previous populations is the analysis of skeletal remains found at mining settlements ${ }^{47}$. Not much research has been conducted in this field, but data available from the Black Forest and Goslar show that mining populations were strongly affected by toxic substances. The examination of the $18^{\text {th }}$ century Goslar miners' population indicated that the lead content in bones increased with age. The lack of difference in the lead intake between men and women proves that everyone was exposed to the same conditions. Since women worked in smelting and were exposed to toxic dust gathering in their houses and on the streets, they suffered from the same toxicity levels ${ }^{48}$. Women commonly worked in mines and even children were employed in ore sorting ${ }^{49}$.

A cemetery connected with a medieval mining settlement was unearthed during an excavation project at the site of Sulzburg "Geißmättle" in the southern Black Forest, where silver-bearing lead ores had been extracted. Skeletal remains of men, women, and children found there provided evidence of such health issues as nutrient deficiency, inflammation, and bone degeneration and fractures, painting a picture of poor living conditions in the region. An analysis of lead levels in the bones was also conducted. The soil in the Sulzburg area is strongly permeated with lead (around $1000 \mathrm{mg} / \mathrm{kg}$ ), so post-mortem lead intake of skeletons was high (up to 1000 $\mathrm{mg} / \mathrm{kg}$ ). Despite that, the inside of the bones showed changes typical of long-term lead poisoning during the individual's lifetime indicating that the population living in the area of Sulzburg must have absorbed high levels of lead throughout their lives. The main source of it was probably the water and food coming from places close to the mining works ${ }^{50}$. Lead presence in bones is a proof of long-lasting intake since short-term intake can only be observed in the blood. In samples collected from bones unearthed in Sulzburg, lead levels ranged between 20 and $350 \mathrm{mg} / \mathrm{kg}$. Comparable lead concentrations can be found in the bones of inhabitants of modern industrial regions with a high rate of lead poisoning related diseases. The lead content discovered in bones was 150 times higher than the level a human organism can tolerate, indicating that

${ }^{42}$ Ibidem, p. 306.

${ }^{43}$ Ibidem, pp. 378-379.

${ }_{44}$ Alt K.W. 2002, p. 384.

${ }^{45}$ Vaněk V., Velebil D. 2007, pp. 188-205.

${ }^{46}$ Kabata-Pendias A., Mukherjee A.B. 2007, p. 390.

47 Schutkowski H. 2002, p. 197.

${ }^{48}$ Ibidem, p. 198.

${ }^{49}$ Wagenbreth O., Wächtler E. 1986, p. 72.

${ }^{50}$ Alt K.W. et al. 1999, pp. 63-72; Alt K.W. 2002, pp. 380-383. 
inhabitants of the Sulzburg region must have suffered from diseases related to lead poisoning ${ }^{51}$. To show the scale it is worth to compare the level of pollution from Sulzburg with non-mining medieval communities. That time people were exposed to lead due to a wide range of application of this heavy metal in every day-use objects (e.g. in coins, seals, windows, glazed pottery), so bioaccumulation of lead was nothing unusual even in non-mining societies. Studies conducted in Denmark on skeletons from medieval urban parish cemetery in Horsens indicated that males displayed an average ( \pm SD) of lead concentrations of $30 \pm 3 \mathrm{mg} / \mathrm{kg}$, whereas for females it was $23 \pm 2 \mathrm{mg} / \mathrm{kg}$ (both values on a log scale) ${ }^{52}$. This demonstrates that Sulzburg inhabitants suffered up to 10 times greater lead poisoning while compared to non-mining societies of the time.

Some historical information about the miners' state of health came from Georgius Agricola. In his work De re metallica, published in 1556, he wrote that miners suffered from anthracosis and rheumatism, as well as from swelling and paralysis caused by harmful fumes. He also mentions that: "for their digging they should make for themselves not only boots of rawhide, but gloves long enough to reach to the elbow, and they should fasten loose veils over their faces; the dust will then neither be drawn through these into their windpipes and lungs, nor will it fly into their eyes. Not dissimilarly, among the Romans the makers of vermilion took precautions against breathing its fatal dust" ${ }^{53}$. Miners also faced a considerable risk of accidents: "workmen slipping from the ladders into the shafts break their arms, legs, or necks, or fall into the sumps and are drowned" 54 . Working in mine was and still is one of the most dangerous occupations. But underground miners and smelters were not the only ones exposed — all humans who lived within a mining area were in danger.

\section{Living conditions in mining regions}

Different forms of settlement and laws also affected the living conditions of miners and their families. In the Middle Ages, miners were free people, who worked for themselves with their families or in small partnerships. Groups of miners settled near places where they found ores. Some settlements were permanent, while others were temporary. A few medieval mining settlements have been discovered in Upper Saxony in Germany, the best preserved of which is Treppenhauer (Fig. 4), where houses were built near mining shafts, sometimes directly on the gangue mounds. Ore crumbling was also conducted close to the houses. Traces of probing processes have been found inside the settlement ${ }^{55}$. An analogical situation has been observed in other medieval mining settlements in Saxony, e.g. Gersdorf (Tiefenbach, Lkr. Mittweida), Ullersberf near Wolkenburg (Lkr. Chemnizer Land), Hohenfors near Kirchberg (Lkr. Zwickauer Land $)^{56}$. Excavations conducted in Altenberg near Müsen (Siegerland region, southern Westfalia, Germany) give an insight into the dynamics of spatial changes in a mining settlement. Some houses were covered by the gangue mounds, while others were dug into them or even sat on closed mining shafts ${ }^{57}$. It is likely that some late medieval mining towns first emerged as small mining settlements formed close to an ore extraction zone. In Kutná Hora, the eponymic settlement of Antiqua Cuthna is localized north of the $14^{\text {th }}$-century town. A survey of the local earthworks revealed traces of mining and dwelling activities there ${ }^{58}$. Similarly, in Banská Štiavnica

51 Schutkowski H. 1999, p. 115.

52 Rasmussen et al. 2015.

53 Agricola G. 1912, p. 215.

54 Ibidem, p. 216.

55 Schwabenicky W. 2009, pp. 169-170.

56 Ibidem, pp. 192-201.

${ }^{57}$ Lobbedey U. 1993, pp. 315-319.

58 Valentová J. 1993, pp. 62-65; eadem 1999, pp. 16-19. 


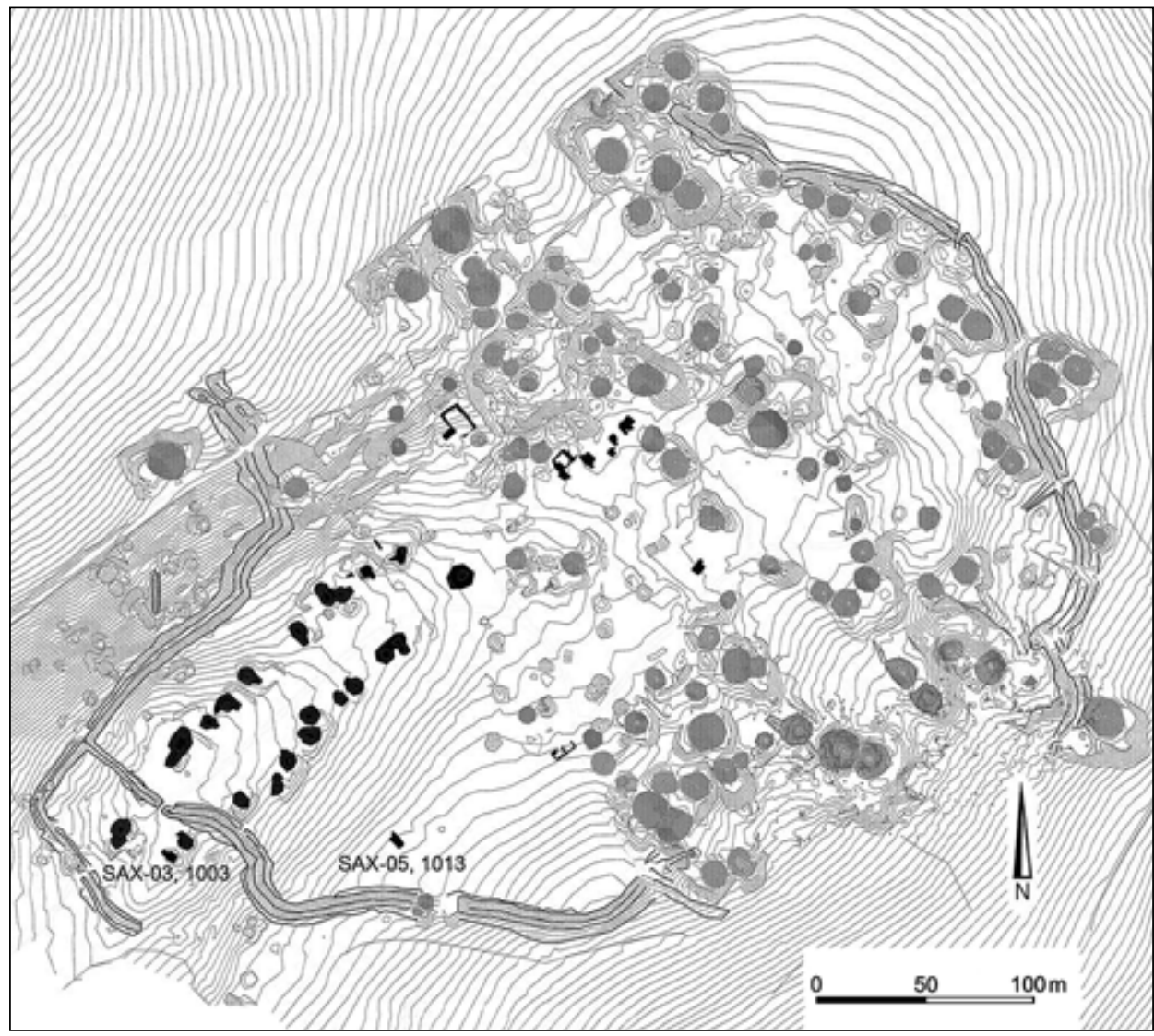

Fig. 4. Treppenhauer - contour map with all surface artificial forms: buildings (black) and shafts (grey) (after Kenzler H. 2008, Abb. 4)

Ryc. 4. Treppenhauer - mapa warstwicowa z zaznaczonymi antropogenicznymi formami terenu: budynki (czarny) oraz szyby górnicze (szary) (za: Kenzler H. 2008: Abb. 4)

(Slovakia), the oldest part of the settlement was on the top Glanzenberg (today known as Stere Mesto $=$ Old Town) close to mining fields (Fig. 5) $)^{59}$.

At the Jihlava Staré Hory (Czech Republic) mining site located close to an ore extraction area, a few buildings were found. They were probably related to ore processing and craftwork but they may have also been used for habitation ${ }^{60}$. Houses were also discovered in the aforementioned site of Cvílinek ${ }^{61}$ and in the mining areas around Freiberg in Neuhilbersdorf and Rammelsberg ${ }^{62}$. It is difficult to establish whether all those structures were permanently used for living, but it is likely that during mining operations some workers lived close to shafts and the processing infrastructure. In the case of more permanent settlements, they were probably accompanied by their families.

\footnotetext{
59 Labuda J. 2004, pp. 261-266.

${ }^{60}$ Hrubý P. 2011, pp. 242-245.

61 Hrubý P. et al. 2012.

${ }^{62}$ Eckstein K. et al. 1994; Richter U. 1995.
} 


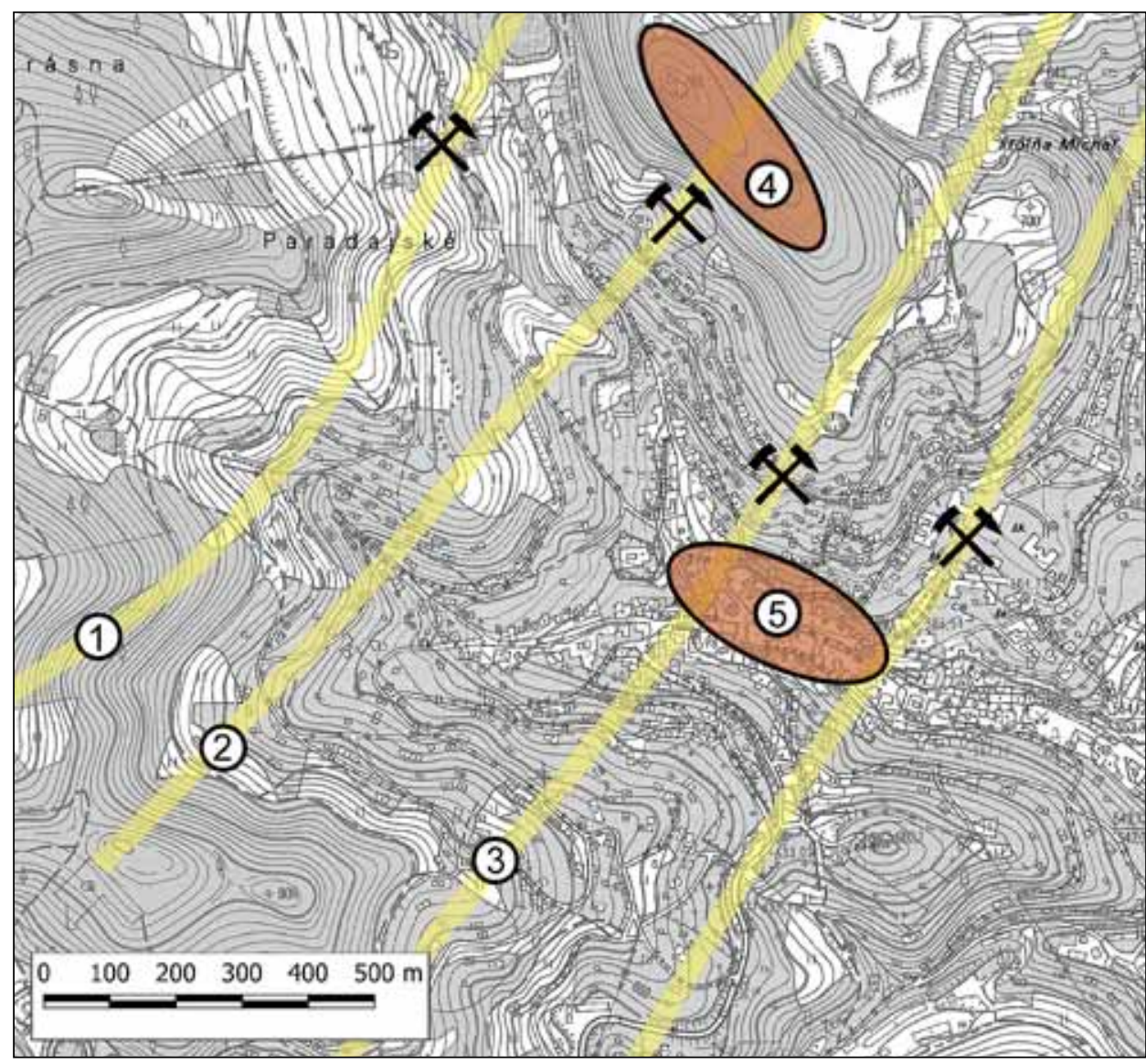

Fig. 5. Banská Štiavnica - relation of the town and mining fields:

1 - Terézia vein; 2 - Bieber vein; 3 - Špitaler vein; 4 - mining settlement and castle on Glanzenberg; 5 - Area of a town (prepared by P. Cembrzyński)

Ryc. 5. Bańska Szczawnica - relacja przestrzenna miasta i pól górniczych:

1 - żyła Terézia; 2 - żyła Bieber; 3 - żyła Špitaler; 4 - osada górnicza i zamek na szczycie Glanzenberg; 5 - obszar miasta (oprac. P. Cembrzyński)

The quality of a miner's life depended heavily on the location of the smelting works and that, in turn, was dictated by the smelting technique used. If ores were rich, furnaces were rather small and built close to the mining area. Bigger smelting apparatus required waterpower and access to fuel. A convenient location of smelters took precedence over that of settlements and they were built in the best possible places. For example, in Banská Štiavnica a pre-locational smelting site had existed in the valley where the town was formed (in the area of later Kammerhof ${ }^{63}$. In Kutná Hora from the $14^{\text {th }}$ to the $16^{\text {th }}$ century, smelters were concentrated southeast of the town centre in the Karlov suburb (Fig. 6). Waste produced there is estimated to have amounted to 500,000 tons $^{64}$. In the $16^{\text {th }}$ century, a few large smelters were built along

${ }^{63}$ Tóthová Š. 1985, 1991.

${ }^{64}$ Bílek J. 2001, p. 58. 


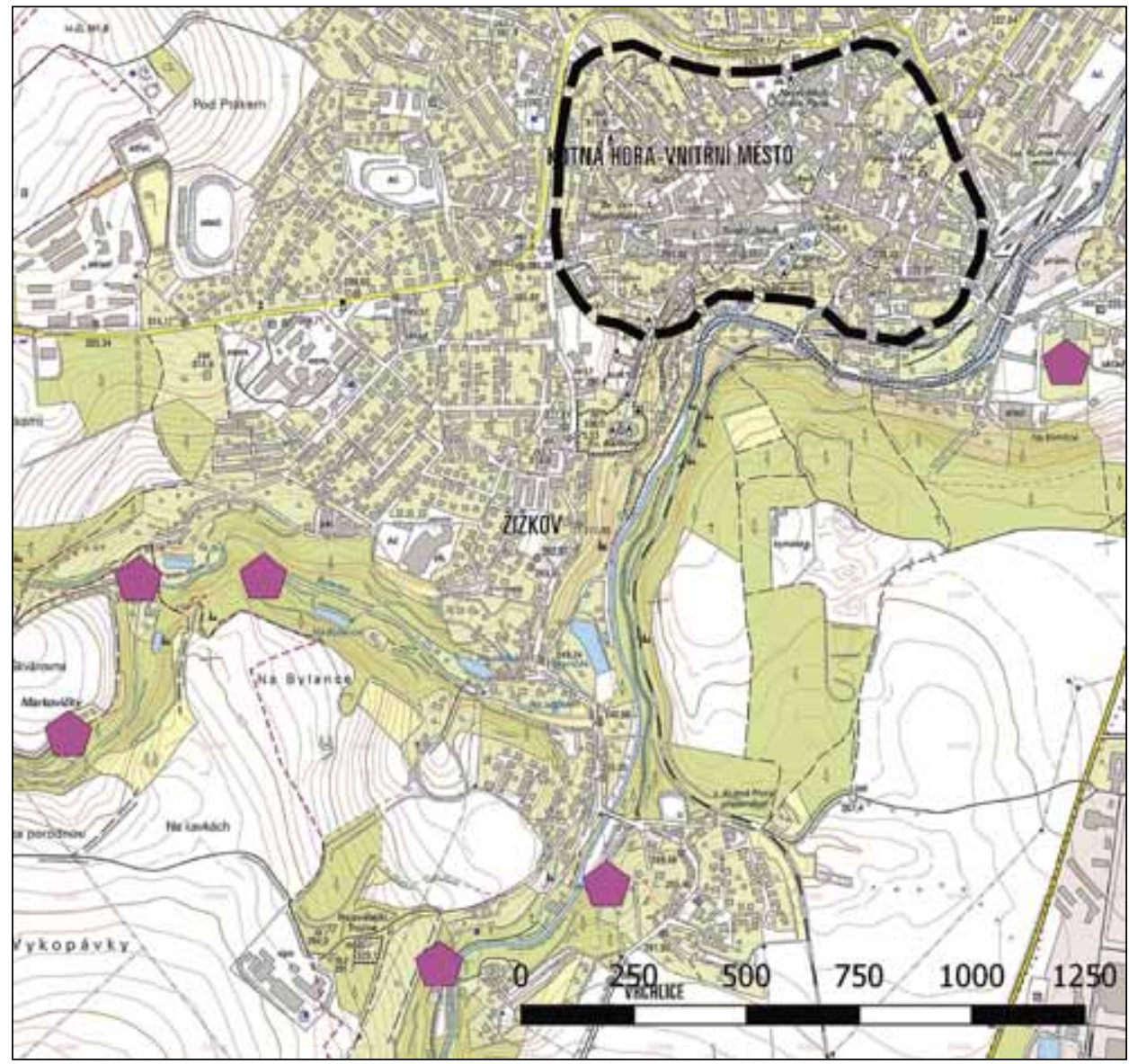

Fig. 6. Smelters (pink pentagons) around Kutná Hora in the $15^{\text {th }}$ and $16^{\text {th }}$ century. Area of a town marked by a space-line (prepared by P. Cembrzyński)

Ryc. 6. Huty (różowe pięciokąty) wokół Kutnej Hory w XV i XVI wieku. Obszar miasta zaznaczono linią przerywaną (oprac. P. Cembrzyński)

the Bylanka and Vichlice streams, on the west side of the town ${ }^{65}$. Historical sources mention that in the $14^{\text {th }}$ century many roasting furnaces and smelters were located in the suburbs of Olkusz $^{66}$. In the Early Modern Era, new large smelters were built on streams far from the town, but still, as late as 1604, 17 small smelters operated outside town walls ${ }^{67}$. Furthermore, smelting sites were traced in close proximity to mining settlements in the Havlíčkův Brod mining district $^{68}$ and they were also located very close to Kremnica ${ }^{69}$ and to Schneeberg ${ }^{70}$. In Tar-

\footnotetext{
65 Ibidem, p. 52.

${ }^{66}$ Molenda D. 1978, p. 166.

${ }^{67}$ Molenda D. 1972, p. 256; eadem 1978, p. 242.

${ }^{68}$ Hejhal P. et al. 2005, pp. 49-66.

69 Štefánik M. 2010, pp. 54-78.

70 Wagenbreth O., Wächtler E. 1990, p. 216.
} 
nowskie Góry, smelting furnaces were located in nearby villages, about $2 \mathrm{~km}$ from the town ${ }^{71}$. In Złoty Stok, they were in the valley just west of the town ${ }^{72}$.

An indication of a smelter being located close to a settlement is the presence of slag inside the dwelling area. Occasionally it was used to toughen roads as observed during excavations in Olkusz, where several layers of "slag-road" were found in the market square. The addition of slag made them very hard and they had a relatively smooth surface (unpublished research from 2010-12 of I. Mianowska). An analogical use of slag was observed in Freiberg ${ }^{73}$ and is known from historical sources related to Tarnowskie Góry ${ }^{74}$. The presence of slag embedded in local roads was also another contamination factor close to human houses.

However, sometimes smelting took place at a considerable distance from human settlements. In Treppenhauer, only traces of probe furnaces were discovered in the settlement areas. The smelting site was located $2 \mathrm{~km}$ from the town, on the bank of a river, where there was access to waterpower ${ }^{75}$. Big smelters required a location with a direct access to fuel supply, sometimes far from settlements or mines. For example, in Banská Bystrica in the late $15^{\text {th }}$ century, the Thurzo-Fugger company built new copper smelters in Moštenica and in Tajov - both locations far removed from the city centre ${ }^{76}$.

In many cases, we do not have the exact information about the location of smelting sites. However, the mentioned examples indicate that they were often close to the settlement. As a source of toxic fumes and dust, they posed a risk to the local population. But even if the smelters were at some distance from human dwellings, they could still contaminate the areas of food production. This contamination would be significant since food was one of the major sources of heavy metal transmission in mining areas.

It is important, therefore, to establish where the sources of food supplies for mining towns and settlements were located. It is hard to specify their placement in every single case, but a wider view on the whole mining district could be helpful in establishing their whereabouts. It is estimated that the local town market's influence zone during pre-modern times was about $15 \mathrm{~km}$, that is a one-day return journey ${ }^{77}$. In a mountainous region like the Ore Mountains, most of the food supply for mining settlements located at higher altitudes were imported from the neighbouring non-mining towns ${ }^{78}$. But in fertile areas such as Moravia, central Bohemia, or Silesia, mining works were carried out among arable fields. For example, agriculture was developed around Kutná $\mathrm{Hora}^{79}$, Olkusz ${ }^{80}$, and Jihlava ${ }^{81}$. Research from the Harz and the Black Forest showed that heavy metals could spread over a wide area, which could overlap with the food production zones, therefore contaminating plants and animals, and, in the end, entering the human diet.

\footnotetext{
${ }^{71}$ Molenda D. 1972, p. 277.

72 Dziekoński T. 1972, pp. 134, 157.

73 Richter U. 2011, p. 63.

${ }^{74}$ Molenda D. 1969, p. 102.

75 Schwabenicky W. 1992, p. 544; idem 2009, pp. 87-90.

76 Skladaný M. 2010, pp. 36, 42.

77 Goliński M. 2005, pp. 49-62.

78 Jančárek P. 1971, pp. 90-96.

${ }^{79}$ Charvátová K. 1993, pp. 32-39.

${ }^{80}$ Molenda D. 1978, p. 189.

${ }^{81}$ Hrubý P. 2011, p. 187; Svěrák V. 2009, pp. 245-316.
} 


\section{VIII. "Ecological awareness" in mining regions and attempts for natural resource protection}

It is difficult to establish how people, during Medieval and Early Modern Times, reacted to the devastated environment, how much did they knew about the threat, and what they were doing with that knowledge. Some information came from the $16^{\text {th }}$-century sources. Georgius Agricola gives us a short description of how the environment looked like: "And when the woods and groves are felled, then are exterminated the beasts and birds, very many of which furnish a pleasant and agreeable food for man. Further, when the ores are washed, the water which has been used poisons the brooks and streams, and either destroys the fish or drives them away. Therefore the inhabitants of these regions, on account of the devastation of their fields, woods, groves, brooks and rivers, find great difficulty in procuring the necessaries of life, and by reason of the destruction of the timber they are forced to greater expense in erecting buildings. Thus it is said, it is clear to all that there is greater detriment from mining than the value of the metals which the mining produces" $" 82$. This excerpt indicates that an awareness of the destructive role of mining existed. It even led some to raise objections. In 1485, Paulus Niavis from Scheeberg published the work Iudicuium Iovis, in which he described a trial of ancient gods over renaissance mining. The gods accused mankind of murdering Mother Earth ${ }^{83}$.

Environmental protection was probably not the most important societal issue during Medieval and Early Modern Era. The concept is a rather late one. The aim of protective actions was to prevent resources from being overexploited as in the case of forests and timber supply. It was essential for the medieval economy and the lack of wood could become a problem very quickly. The first forest-protecting regulations in medieval towns date to the $14^{\text {th }}$ century ${ }^{84}$, and more forest protection laws and timber and charcoal production regulations were passed in the $14^{\text {th }}$ and $15^{\text {th }}$ centuries ${ }^{85}$. The first mining town that introduced forest restrictions (Waldbann) was Amberg (Bayern) in $1310^{86}$, but in the Jihlavian Mining Law, codified in the $14^{\text {th }}$ century, there was no such regulation ${ }^{87}$. It seems that to the mining industry of Central-Eastern Europe protecting the forest was not an important issue at the time. It took a long time to perceive this necessity and consider a change in the legal provisions. Forest orders in mining regions became necessary in the $16^{\text {th }}$ century during the phase of rapid growth. The Jáchymov mining law, passed in 1518, still did not provide forest protection at all. However, only a few years later, in 1525, an official responsible for the forestry was appointed. More regulations started appearing during the following decades ${ }^{88}$.

The earliest laws were passed in towns located far away from rivers used for the transportation of wood, e.g. Nuremberg or Erfurt. Town councils tried to regulate access to municipal forests by limiting pig and sheep pasture, by determining the ratio of timber per citizen, and if possible, by relocating wood-consuming crafts, e.g. ironworks or glassworks, to more resourcerich places. Sometimes, they also tried to restore woodlands. The first artificial seeding in Central Europe took place in 1369 in Nuremberg ${ }^{89}$. Additionally, in Nuremberg, the trees, the seeds of which were eaten by pigs and wild game, were specially protected (oak, beech $)^{90}$. In

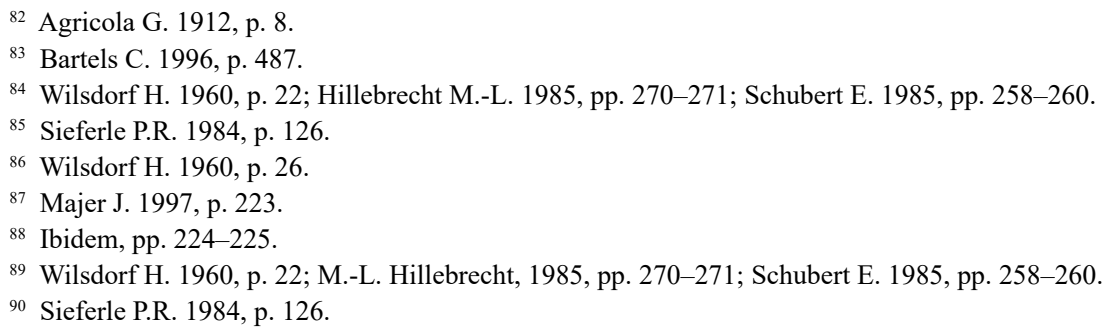


Jáchymov, at first, cutting down a tree was free for all miners and town dwellers, but in 1535 a small fee for wood consumption was introduced. It was forbidden to grub up trees to set up fields, gardens, and pastures. Although the law required that trees should be cut down close to the ground, sick trees removed from the forest, young trees protected, and new ones planted after cutting down the old ones, it was never enforced, and the situation became nearly critical. Finally, in 1556, foresters from Tirol were hired to plant conifers. At that time, any persons causing damage to the forest were sentenced to corporal punishment. Nevertheless, all these measures did not bring results until the late $16^{\text {th }}$ century ${ }^{91}$.

The best way of dealing with the lack of wood was the introduction of woodland management. Coppicing was a common method applied in the Middle Ages. Tree trunks were cut down close to the ground every 18-20 years, so their diameters remained small. The species that were the most suitable for growing in such a kind of a forest were hazel, linden, ash, and maple. Coppicing was probably used in the area around site Treppenhauer, a mining settlement in the valley of the River Zschopau (Upper Saxony, Germany). The mines and mining settlements in the region operated in the $13^{\text {th }}$ and $14^{\text {th }}$ centuries. They were established within an area colonized before, so most of the natural forest had been cut down even before the mining started. Charcoal unearthed during archaeological excavations at this site came mostly from linden, birch, and hazel, and only in a small part from fir and beech, which suggests that coppicing was applied as a form of woodland management. Timber from the coppiced forest was used as fuel, charcoal, and framing, as well as wattle and daub constructions ${ }^{92}$. In fact, it is possible that with a balanced economy, the forest had production capabilities sustainable over a long time. The examples of sustainable forest management are known from some places in Europe ${ }^{93}$. It is difficult to say whether this kind of woodland management was common in mining regions. Treppenhauer was a relatively small site, so its demand for wood would have been small. Most data regarding problems with wood supply come from bigger mining centres (Banská Bystrica, Olkusz, Jáchymov), where mining operations were carried out for a long time and on a much larger scale.

Finally, there might be one other thing that increased the impact of mining on the environment: changes in the social organization of the mining. Medieval and early modern mining demanded very risky large-scale investments with little guarantee of profit or even return. The $13^{\text {th }}$ and $14^{\text {th }}$-century mining could rely on small groups of free miners and their families who extracted ores from easy to access deposits ${ }^{94}$. When the scale of mining works rose, miners started to organize themselves in companies to share costs and profits between a greater number of people ${ }^{95}$. But that was not enough to handle such problems, as the need to mine deeper or to drain shafts. Help came from the merchants who traded metals since they had enough money to maintain production. After them came the bankers and nobles looking for new investment opportunities. They formed large companies (like the Fuggers family, or companies of Polish nobles and merchants) who had a lot of money. Unfortunately, developing long-term, sustainable strategies was not their strongest skill since they tried to maximize profits and minimize costs. The easiest way to achieve that was through overexploitation ${ }^{96}$. As the demand for raw materials (e.g., timber) increased, unprofitable mines were abandoned. It led to environmental destruction and, in many places, to the collapse of the mining industry. The only ones who

91 Majer J. 1997, pp. 224-228.

92 Schwabenicky W. 2009, pp. 233-235.

93 Iles L.E. 2016.

94 Nef J.U. 1987, p. 713.

95 Molenda D. 1963, pp. 138-139.

96 Molenda D. 1992, pp. 83-91; eadem 1963, pp. 138-141. 
never suffered from environmental damage were investors, who lived in rich trading centers, far away from the compromised surroundings of their mines.

\section{Conclusion}

Mining and smelting operations affected the lands in their immediate vicinity. The most visible effect was deforestation caused by the demand for fuel and building materials. However, there is no general model of miner-forest relations, as every region and every kind of production was unique. The pace of the destruction process also differed between mining centres. It could be slowed down by proper forestry (coppicing). Similarly, mining had an adverse impact on the soils and landscape. Because of the search and extraction of ore aggravated by deforestation, many areas became exposed to erosion, a phenomenon best observed in the mountainous regions, but just as catastrophic in the lowlands. Because of the lack of more detailed estimates, it is impossible to gauge the scale of ground degradation in the Middle Ages and the Early Modern Era.

During all stages of the metal production process, toxic substances, especially heavy metals, were released into the environment. In the primary processing, it was mostly small particles of the ore that were dumped close to the mines. At this stage, the washing-out process posed the greatest risk. Some toxic elements were transported by water over large distances, far away from the mining districts and into food producing lands. The most dangerous substances were released during the smelting process. Most of them heavily polluted areas immediately adjacent to the smelting sites, some fell back on the ground with precipitation at some distance, and only a small percentage were transported far away from their source.

People living in mining areas were exposed to many hazards, i.e. physical dangers in mines (accidents), as well as poisoning by toxic fumes and through the process of a slow intake of heavy metals with food and water. It is very likely that miners were aware of the danger but optimizing the metal production came before protecting their health as indicated by the presence of smelters close to dwelling areas and by some house relics sitting close to mining shafts and the primary processing infrastructure. Without a doubt, during the Middle Ages and the Early Modern Period, production intensification and changes in miners' social organization led to a general decrease in the quality of life in mining regions.

Proofread by

Karolina Frank

Adress of the Author:

dr Paweł Cembrzyński

Institute of Archaeology and Ethnology

Polish Academy of Science

Al. Solidarności 105

00-140 Warszawa

pawelcembrzynski@op.pl

ORCID: 0000-0002-8515-7669 


\section{BIBLIOGRAPHY}

Agricola, Georgius. 1912. De Re Metallica Translated from First Latin Edition of 1556 by Herbert Clark Hoover, London.

Alt Kurt W. 2002. Lebensbedingungen und Lebensumstände von Kindern im Mittelalter am Beispiel einer Bergbaubevölkerung, [in:] Regio Archaeologica. Archäologie und Geschichte an Ober- und Hochrhein. Festschrift für Gerhard Fingerlin zum 65. Geburtstag. Internationale Archäologie. Studia Honoraria 18, ed. C. Bücker et al., Radhen, pp. 373-388.

Alt Kurt W., Lohrke Brigitte, Brenn Rüdger, Becker Thomas. 1999. Umwelt- und Lebensbedingungen einer Mittelalterlichem Bergbau Bevölkerung aus Sulzburg (Kr. Breisgauß-Hochschwarzwald), [in:] Früher Bergbau Im Südlichen Schwarzwald, (Archäologische Informationen aus Baden-Württemberg 41), ed. R. Gottschalk, Stuttgart, pp. 63-72.

Bartels Christoph. 1996. Mittelalterlicher und Frühneuzeitlicher Bergbau im Harz und seine Einflüsse auf die Umwelt, "Naturwissenschaften", vol. 83, pp. 483-491.

Bartoš Martin. 2004. Vodní náhony a plavební kanály v kutnohorském rudním revíru, "Kutnohorsko-Vlstivědný Sborník", vol. 7/04, pp. 18-24.

Bílek Jaroslav. 2001. Kutnohorské dolování. 9. Historický přehled. K problematice poddolování, hald a vrchlické přehrady, Kutná Hora.

Bohdálková Leona, Erbanová Lucie. 2013. Geochemické archivy a možnosti jejich použiti v montánní archeologii, [in:] ArchaeoMontan 2012. Erkunden - Erfassen - Erforschen. Internationale Fachtagung Dippoldiswalde 18. bis 20. Oktober 2012, ed. R. Smolnik, Dresden, pp. 83-86.

Breitenlechner Elisabeth, Hilber Marina, Lutz Joachim, Kathrein Yvonne, Unterkircher Alois, Oeggl Klaus. 2010. The impact of mining activities on the environment reflected by pollen, charcoal and geochemical analyses, "Journal of Archaeological Science", vol. 37, pp. 1458-1467.

Bühler Hans-Eugen, Wild Heinz Walter. 1991. Umweltprobleme bei der Kupferverhüttung im Mittelalter, "Erzmetall", vol. 44, pp. 154-161.

Cembrzyński Pawel, Legut-Pintal Maria. 2014. Airborne Laser Scanning as a Method of Localisation and Documentation of Mining Sites Remains. Examples from Silesia " "Acta Rerum Naturalium", vol. 16, pp. 187-202.

Charvátová Kateřina. 1993. Středověké dvory sedleckého klastera, "Památky středních Čech", vol. 7, pp. 32-39.

Czaja Stanisław. 1996. Antropogeniczne przemiany stosunków wodnych w rejonie Tarnowskich Gór od XIV do końca XIX wieku, [in:] Dziejowe przemiany stosunków wodnych na obszarach zurbanizowanych, ed. A.T. Jankowski, A. Kaniecki, Poznań-Sosnowiec, pp. 14-30.

Deicke Matthias. 2000. Findings concerning the environmental history of the Harz Mountains and the Utilization of Mineral Resources, [in:] Aspects of Mining and Smelting in the Upper Harz Mountains (up to the 13th/14th Century) in the Early Times of a Developing European Culture and Economy, Siegener Abhandlungen zur Entwicklung der materielle Kultur 32, ed. Chr. Segers-Glocke, H. Witthöft, St. Katharinen, pp. 66-78.

Delumeau Jean. 2015. Cywilizacja Odrodzenia, Warszawa.

Dziekoński Tadeusz. 1972. Wydobywanie i metalurgia kruszców na Dolnym Śląsku od XIII do połowy XX wieku, Wrocław.

Eckstein Karsten, Hauptmann Andreas, Rehren Thilo, Richter Uwe, Schwabenicky Wolfgang. 1994. Hochmittelalterliches Montanwesen im sächsischen Erzgebirge und seinem Vorland, "Der Anschnitt", vol. 46, pp. 114-132.

Frenzel Burkhard, Kempter Heike. 2011. Frühe Umweltverschmutzungen: Die Schwermetallablagerungen in Schwarzwälder Hochmooren, [in:] Silber, Kupfer, Kobalt - Bergbau im Schwarzwald, ed. G. Markl, L. Sönke, Filderstadt, pp. 99-130.

Frolík Jan, Tomášek Martin. 2002. Kutná Hora. Přispěvek archeologie k nejstarši topografii a komunikačnimu schèmatu města, [in:] Civitas et Villa. Miasto i wieś w średniowiecznej Europie Środkowej, ed. C. Buśko, Wrocław, pp. 99-107. 
Gawlas Sławomir 2006. Komercjalizacja jako mechanizm europeizacji peryferii na przykładzie Polski, [in:] Ziemie polskie wobec Zachodu. Studia nad rozwojem średniowiecznej Europy, ed. S. Gawlas, Warszawa, pp. 25-116.

Gawlas Sławomir. 1996. O kształt zjednoczonego Królestwa, Warszawa.

Gleitsmann Rolf-Jürgen. 1984. Der Einfluß der Montanwirtschaft auf die Waldentwicklung: Stand und Aufgaben der Forschung Mitteleuropas, [in:] Montanwirtschaft Mitteleuropas vom 12. bis 17. Jahrhundert: Stand, Wege und Aufgaben der Forschung. Der Anschnitt. Beiheft 2, ed. W. Kroker, E. Westermann, Bochum, pp. 24-39.

Le Goff Jacques. 2002. Kultura średniowiecznej Europy, Gdańsk-Warszawa.

Goldenberg Gert. 1996. Umweltbeeinflussung durch das frühe Montanwesen. Beispiele aus dem Schwarzwald, [in:] Bergbau, Verhüttung und Waldnutzung im Mittelalter. Auswirkungen auf Mensch und Umwelt, ed. A. Jockenhövel, Stuttgart, pp. 230-246.

Goldenberg Gert. 1993. Frühe Umweltbelastungen durch Bergbau und Hüttenwesen, [in:] Alter Bergbau in Deutschland (Archäologie in Deutschland. Sonderheft), ed. H. Steuer, U. Zimmerman, Stuttgart, pp. 107-113.

Goliński Mateusz. 2005. Miasta a polityka gospodarcza Henryka IV Probusa, [in:] Ślask w czasach Henryka IV Prawego, ed. K. Wachowski, Wratislavia Antiqua, vol. 8, Wrocław, pp. 49-62.

Hejhal Petr, Hrubý Petr, Malý Karel, Rous Pavel, Vokáč Marti, Zimola David. 2005. Dolování drahých kovủ na Českomoravské Vrchovinè, [in:] Montána archeológia na Slovensku (25 rokov výskumu lokality Glanzenberg v Banskej Štiavnici). Medzinárodný seminár 7.9.-9.9.2005 Banska Stiavnica — Starý Zámok, ed. J. Labuda, Banska Štiavnica, pp. 49-66.

Hillebrecht Marie-Luise. 1989. Energiegewinnung auf Kosten der Umwelt, "Berichte zur Denkmalpflege in Niedersachsen", vol. 9 (2), pp. 80-85.

Hillebrecht Marie-Luise. 1985. Eine mittelalterliche Energiekrise, [in:] Mensch und Umwelt im Mittelalter, ed. B. Hermann, Köln, pp. 270-278.

Hillebrecht Marie-Luise. 1982. Die Relikte der Holzhohlwirtschaft als Indikatoren für Waldnutzung und Waldentwicklung. Untersuchungen an Beispielen aus Südniedersachsen, Göttinger geographische Abhandlungen, H. 79, Göttingen.

Hrubý Petr. 2011. Jihlava - Staré Hory. Archeologický výzkum středověkého důlního, úpravnického a obytného areálu v letech 2002-2006. Přispěvek ke studio středověkého rudného hornictví, Praha.

Hrubý Petr, Hejhal Petr, Hoch Aleš, Kočár Petr, Malý Karel, Macháňová Lenka, Libor Petr, Štelcl Jindřich. 2012. Středověký úpravnický a hornický areál Cvilínek u Černova na Pelhřrimovsku, "Památky Archeologické", vol. 103, pp. 339-418.

Iles Louise Elizabeth. 2016. The Role of Metallurgy in Transforming Global Forests, "Journal of Archaeological Method and Theory", vol. 23 (4), pp. 1219-1241.

Jančárek Petr. 1971. Města českeho Krušnohoři v předbělohorské době. Přispevek $k$ studiu jejich socjalni struktury, Ústí nad Labem.

Kabata-Pendias Alina, Mukherjee Arun B. 2007. Trace Elements from Soil to Human. Berlin, Heidelberg.

Kabata-Pendias Alina, Piotrowska Maria. 1995. Podstawy oceny chemicznego zanieczyszczenia gleb: metale ciężkie, siarka $i$ WWA, Warszawa.

Kenzler Hauke. 2008. Struktur und Entwicklung der Bergstadt auf dem Treppenhauer. Ergebnisse der archäologischen Untersuchungen von 2005 bis 2007, "Arbeits- und Forschungsberichte zur sächsischen Bodendenkmalpflege”, vol. 50, pp. 263-306.

Kořan Jan. 1950. Dějiny dolování v rudním okrsku kutnohorském, Praha.

Labuda Jozef. 2004. Banská Štiavnica jako priklad osidlovania banských regionom, “Archaeologia Historica", vol. 29, pp. 261-266.

Lobbedey Uwe. 1993. Der Altenberg bei Müsen (Siegerland) eine Bergbauwüstung des 13. Jahrhunderts, [in:] Montanarchäologie in Europa. Berichte zum Internationalen Kolloquium ,Frühe 
Erzgewinnung und Verhüttung in Europa " in Freiburg in Breisgau vom 4. bis 7. Oktober 1990, ed. H. Steuer, U. Zimmerman, Sigmaringen, pp. 315-319.

Ludemann Thomas. 2010. Past Fuel Wood Exploitation and Natural Forest Vegetation in the Black Forest, the Vosges and Neighbouring Regions in Western Central Europe, "Palaeogeography, Palaeoclimatology, Palaeoecology", vol. 29, pp. 154-165.

Majer Jiř́. 1997. Die Waldwirtschaft und die Holzverwenderung im Silbererzrevier Jáchymov/Joachimsthal im Erzgebirge und im Zinnerzrevier Horni Slavkov/Schlaggenwald im Kaiserwaldgebirge im 16. Jahrhundert, [in:] Bergbaurevier als Verbrauchszentren im vorindustriellen Europa, Fallstudien zu Beschaffung und Verbrauch von Lebensmitteln sowie Roh- und Hilfsstoffen (13.-18. Jahrhundert), ed. E. Westermann, Stuttgart, pp. 221-248.

Małowist Marian. 2006. Wschód a Zachód Europy w XIII-XVI wieku, Warszawa.

Molenda Danuta. 1992. Upadek miast górniczych w Małopolsce i na Górnym Ślasku w XVII i XVIII w., [in:] Miasto, region, społeczeństwo: studia ofiarowane profesorowi Andrzejowi Wyrobiszowi w sześćdziesiąta rocznicę Jego urodzin, ed. E. Dubas-Urwanowicz, J. Urwanowicz, Białystok, pp. 83-91.

Molenda Danuta. 1978. Dzieje Olkusza do 1795 r., [in:] Dzieje Olkusza i Regionu Olkuskiego, vol. I, ed. F. Kiryk, R. Kołodziejczyk, Warszawa-Kraków, pp. 147-340.

Molenda Danuta. 1972. Kopalnie rud ołowiu na terenie złóż śląsko-krakowskich w XVI-XVIII wieku, Wrocław.

Molenda Danuta. 1969. Piastowskie Wolne Miasto Górnicze Tarnowskie Góry, [in:] Tarnowskie Góry. Zarys dziejów powiatu, ed. H. Rechowicz, Katowice, pp. 93-118.

Molenda Danuta. 1963. Górnictwo kruszcowe na terenie złóż śląsko-krakowskich do połowy XVI wieku, Wrocław-Warszawa-Kraków.

Nef John U. 1987. Mining and Metallurgy in Medieval Civilization, [in:] The Cambridge Economic History of Europe, Vol. 2: Trade and Industry in the Middle Ages, ed. M.M. Postan, E. Miller, Cambridge, pp. 693-761.

Patterson C.C., Chow Tsaihwa J., Murozumi Masayo. 1970. The Possibility of Measuring Variations in the Intensity of Worldwide Lead Smelting during Medieval and Ancient Times Using Lead Aerosol Deposits in Polar Snow Strata, [in:] Scientific Methods in Medieval Archaeology. UCLA Center for Medieval and Renaissance Studies Contributions, IV, ed. R. Berger, pp. 339-350.

Pierzak Jacek, Rozmus Dariusz. 1997. Badania ratownicze na terenie osady hutniczej z XVI wieku w Hutkach, Województwo Katowickie, "Badania Archeologiczne na Górnym Śląsku i Ziemiach Pogranicznych w 1993 roku”, pp. 188-193.

Pierzak Jacek, Rozmus Dariusz, Roś Jerzy. 2004. Osady produkcyjne w Hutkach k. Olkusza, [in:] Archeologiczne i historyczne ślady hutnictwa i górnictwa na terenie Dabrowy Górniczej i okolic, ed. D. Rozmus, Kraków, pp. 81-92.

Rasmussen Kaare Lund, Skytte Lilian, Jensen Anne Juul, Boldsen Jesper Lier. 2015. Comparison of Mercury and Lead Levels in the Bones of Rural and Urban Populations in Southern Denmark and Northern Germany during the Middle Ages, "Journal of Archaeological Science: Reports", vol. 3, pp. 358-370.

Richter Uwe. 1995. Archäologische Untersuchungen in Freiberg. Neue Erkenntnisse zur Frühgeschichte der Stadt, "Stadt- und Bergbaumuseum Freiberg, Schriftenreihe", 12.

Richter Uwe. 2011. Der Freiberger Bergbau in der ersten Bergbauperiode: Grabungen - Funde - Denkmale, [in:] Aufbruch Unter Tage. Stand und Aufgaben der montanarchäologischen Forschung in Sachsen, Arbeits- und Forschungsberichte zur Sächsischen Bodendenkmalpflege, Beiheft 22, ed. R. Smolnik, Dresden, pp. 61-68.

Ruppert Hans, Deicke Matthias. 2006. Source of Medieval Lead Enrichments in Natural Archives of Europe: Harz Mts. (Germany), "Geochimica et Cosmochimica Acta. Supplement", vol. 70, no. 18, p. A545.

Schubert Ernst. 1985. Der Wald: wirtschaftliche Grundlage der Spätmittelalterlichen Stadt, [in:] Mensch und Umwelt im Mittelalter, ed. B. Hermann, Köln, pp. 252-269. 
Schutkowski Holger. 2002. Mines, meals and movement. A human ecological approach to the interface of "history and biology", [in:] Human Biology and History, ed. M. Smith, CRC Press, pp. 195-211.

Schutkowski Holger. 1999. Mittelalterliches Schadstoffrisiko — das Beispiel der Sulzburg Bergleute, "Archäologische Nachrichten aus Baden-Württemberg", vol. 61/62, pp. 114-117.

Schwabenicky Wolfgang. 2009. Der mittelalterliche Silberbergbau im Erzgebirgsvorland und im westlichen Erzgebirge, Chemnitz.

Schwabenicky Wolfgang. 1992. Der Mittelalterliche Silber-, Blei- und Kupferbergbau im Mittlern und westlichen Erzgebirge sowie im Erzgebirgsvorland unter besonderer Berücksichtigung der Grabungsergebnisse vom Treppenhauer bei Sachsenburg, "Etnographisch-Archäologische Zeitschrift", vol. 33, pp. 541-552.

Sieferle Peter Rolf. 1984. Vom Holz zur Kohle. Die Energiekriese im 18. Jahrhundert und ihre Lösung, "Der Anschnitt", vol. 36, pp. 124-135.

Skladaný Marian. 2010. Banská Bystrica, [in:] Lexikon stredovekých miest na Slovensku, ed. M. Štefánik, J. Lukačka, Bratislava, pp. 29-51.

Štefánik Martin. 2010. Kremnica, [in:] Lexikon stredovekých miest na Slovensku, ed. M. Štefánik, J. Lukačka, Bratislava, pp. 54-78.

Straßburger Martin, Tegel Willy. 2009. Holznutzung und Bergbau im Schwarzwald während des Mittelalters und der Neuzeit, "Der Anschnitt", vol. 61, pp. 182-192.

Svěrák Vlastimil. 2009. Velké Století/1526-1619, [in:] Jihlava - Historie, Kultura, Lidé, ed. R. Pisková, M. Bartlová, Praha, pp. 245-316.

Tóthová Štefánia. 1985. Mestská Pamiatková Rezervácia Banská Štiavnica — výsledky archeologických výskumov, "Archaeologia Historica”, vol. 10, pp. 125-132.

Tóthová Štefánia. 1991. Výsledky archeologického výskumu v Banskej Štiavnci, [in:] Banské mestá na Slovensku, ed. R. Marsina, Žiar nad Hronom, pp. 50-65.

Valentová Jarmila. 1993. Antiqua Cuthna - zaniklá středověká hornická osada na katastru Kutné Hory, "Archeologia Technica", vol. 8, pp. 62-65.

Valentová Jarmila. 1999. Hornická osada Antiqua Cuthna - realita pohledem archeologického výzkumu, "Kutnohorsko-Vlstivědný Sborník", vol. 1/99, pp. 16-19.

Vaněk Václav, Velebil Dalibor. 2007. Staré hutnictví střibra, [in:] Střibrná Jihlava 2007. Studie $k$ dějinám hornictvi a důlních prací, Brno-Jihlava, pp. 188-205.

Wagenbreth Otfried, Wächtler Eberhard. 1986. Der Freiberger Bergbau. Technische Denkmale und Geschichte, Leipzig.

Wagenbreth Otfried, Wächtler Eberhard. 1990. Bergbau im Erzgebirge. Technische Denkmale und Geschichte, Leipzig.

Wilsdorf Helmut. 1960. Holz, Erz, Salz. Das Transportproblem in Montanwesen, [in:] Bergbau, Wald, Floesse. Untersuchungen zur Geschichte der Flößerei im Dienste des Montanwesens und zum montanen Transportproblem. Mit einer kritischen Bibliographie: Schriften zum Thema Wald und Flöße, Berlin, pp. 4-183.

\section{EKOLOGIA GÓRNICTWA. CZŁOWIEK A ŚRODOWISKO W ŚREDNIOWIECZNEJ I WCZESNONOWOŻYTNEJ EUROPIE ŚRODKOWEJ}

Artykuł przedstawia ocenę warunków życia mieszkańców obszarów górniczych w kontekście wpływu górnictwa i hutnictwa na środowisko naturalne w okresie od średniowiecza do wczesnej nowożytności. Studia te powstały na podstawie znalezisk z terenu Schwarzwaldu, Gór Harzu, czeskich i niemieckich Rudaw, Śląska i Małopolski oraz Czech, Moraw i obecnej Słowacji. 
Działalność kopalń i hut oddziaływała przede wszystkim na tereny w bezpośrednim sąsiedztwie. Najbardziej widoczną zmianą w środowisku naturalnym było wylesienie spowodowane wyrębem, w związku z zapotrzebowaniem na opał i materiał budowlany. Tempo wylesiania różniło się w zależności od typu złóż i stosowanej technologii górniczej. Mogło być jednak spowolnione, jeżeli prowadzono odpowiednią gospodarkę leśną. Zniszczenia w drzewostanie potęgowane były przez odkrywki górnicze i generalne, następujące przekształcenia powierzchni terenu. Procesy te powodowały erozję, a w niektórych rejonach pustynnienie.

$\mathrm{Na}$ wszystkich etapach procesu produkcji uwalniane do środowiska były toksyczne substancje, takie jak ołów, miedź, kadm i arsen. Zanieczyszczone nimi odpady wstępnej obróbki (kruszenie, mielenie) składowane były przeważnie w pobliżu kopalń. Część z nich, w trakcie płukania rudy, trafiała bezpośrednio do cieków wodnych. Tą drogą toksyczne pierwiastki transportowane były na znaczne odległości, nawet na położone z dala od rejonów górniczych tereny produkcji żywności. Najniebezpieczniejsze substancje uwalniane były podczas procesu wytapiania. Większość z nich osiadała w pobliżu hut, a ich stężenie malało wraz z odległością.

$\mathrm{Na}$ zdegradowanych i zanieczyszczonych terenach żyli górnicy i hutnicy z rodzinami oraz ludność pośrednio pracująca na rzecz górnictwa. Wszyscy oni wchłaniali toksyczne substancje poprzez pożywienie, wodę i inhalację, co mogło prowadzić do licznych schorzeń, a nawet powodować wzrost śmiertelności. Jest bardzo prawdopodobne, że ludność ta była świadoma zagrożenia, ale optymalizacja kosztów produkcji była istotniejsza niż zdrowie. Świadczy o tym powstawanie zabudowań mieszkalnych w pobliżu hut oraz umieszczanie stałych osiedli niedaleko miejsc wydobycia i wstępnego przerobu surowców. Bez wątpienia w średniowieczu i w okresie wczesnonowożytnym intensyfikacja produkcji i zmiany w organizacji społecznej górników doprowadziły do ogólnego obniżenia jakości życia w regionach górniczych. 
